\title{
Transitivity System as a Tool for Producing (In)accurate Mental Images through Translation
}

\author{
Ali Almanna \\ Head of the Department, \\ English Language and Literature, \\ Al-Zahra College for Women, Oman
}

Doi: 10.36941/jesr-2020-0oo3

\begin{abstract}
The ultimate objective of this study is to show some of the contributions of Halliday's transitivity model to the actual act of translating between two languages that are culturally distant, such as Arabic and English. To this end, I have analysed the translation of a short story, and then compared it with its source text, based on Halliday's (1994) transitivity model. Halliday's transitivity model has been adopted in the current study as it offers effective toolkits to analyse and describe the original text. It produces a repertoire of features of the original text, which can be compared to the corresponding profiles of the target text with the aim of identifying a) the similarities and differences between the source text and the target text and $b$ ) whether the translators have produced an accurate mental image or not. Added to this, this study intends to determine whether this model can be used as a theoretical framework for analysing certain socio-cultural experiences encoded linguistically in a text, regardless of the language itself. It has been shown from the discussion of the data that this model does not confine itself to English only, but can be applied to other languages such as Arabic. Further, the processes along with their participants and circumstances utilized by the writer in the current study lend themselves easily to equivalent processes in the target language. Again, it has been shown that in order to produce an accurate mental image, it is not enough to pay extra attention to the process itself along with its participants and circumstances, but adequate consideration should also be given to the interaction between the participants of the process and the flow of energy, force dynamics, scope of attention, time lapse and metaphorization.
\end{abstract}

Keywords: action-chain schema, Arabic-English translation, distribution of attention, force dynamics, image, time lapse and transitivity system

\section{Introduction}

The idea of highlighting the importance of taking into account the image(s) conjured up in the mind of the translator while dealing with the text at hand comes from personal experiences. First, as a translation teacher for several years, I have been adopting this technique along with many other techniques: that is, focusing on reflecting the mental image, not simply reflecting the linguistic elements that conceptualize the socio-cultural experiences presented in the text, and thus using the mental image to test the translation accuracy. I have been encouraging my students to translate the text at hand more accurately and adequately by reading (in order to have a mental image by adopting a bottom-up process), analysing (by adopting a syntactic parsing approach), and making a pretransferring adjustment at different levels (but without any change to the semantic load of the clause, 
i.e. without any change to the mental image conjured up in their mind dramatically, although they are allowed to delete, add, re-order, etc.). Second, as a literary translator, I have been focusing on producing similar mental images while translating the text at hand.

In this paper, it is suggested that in addition to giving full consideration to the linguistic elements (be they grammatical, semantic, pragmatic, stylistic, etc.) that are used by language users to conceptualize certain socio-cultural experiences, translators need to take into account the different images conjured up in their minds while translating the text. Focusing on the image(s) can be used by 1) the translators themselves to annotate their own translations or comment on others', 2) the critics, revisers and reviewers to evaluate/assess/review the translation, and 3) the translation instructors to analyse and evaluate their students' translations.

The ultimate objective of this study is to show some of the contributions of Halliday's transitivity model to the actual act of translating a text. More specifically, the objective of this study is to use the processes of the transitivity system as parameters for testing the reflection of the image(s) conjured up in the minds of the translators while handling the text at hand. The image can be studied from different perspectives. However, in this study, because of space limitations, the image will be studied by focusing on the different transitivity processes along with their obligatory and optional participants and circumstances. My choice of transitivity system as a theoretical framework is motivated by a general dissatisfaction with existing theoretical frames that translation scholars and researchers tend to draw on in an attempt to explain the local strategies adopted by the translators while dealing with the text at hand.

\section{Scope of the Study}

This study mainly falls in the area of translation research studies that focus on the textual level. According to Chesterman (2005: 23), this type of translation research studies focuses on

texts themselves, as linguistic data in written or oral form; textual research looks at the relations between translations, their source texts, and parallel non-translated texts in the target language. It is thus interested in concepts such as equivalence, naturalness and fluency, and in the possibility of finding universal or very general features of translations as texts of a distinctive kind.

However, it also gives some consideration to the cognitive level, that is to say, it pays attention to the decision-making processes in the translators' minds, and how they are influenced by such factors as their attitudes, backgrounds, professional experiences, accumulative value system, sociocultural experiences, encyclopedic knowledge, and so on (these issues will not be discussed in detail here due to space constraints). In this regard, Chesterman (p.23) holds that although the areas of translation studies can be roughly separated into four levels, viz. the textual level, cognitive level, sociological level, and cultural level, "there is of course much research that cannot be placed easily into one box or another, and overlaps are common".

The current paper employs qualitative research methodology, which, as O'Leary (2010:113) argues,

calls on inductive as well as deductive logic, appreciates subjectivities, accepts multiple perspectives and realities, recognizes the power of research on both participants and researchers, and does not necessarily shy away from political agendas.

The level of data utilized in this study is micro. Unlike macro-level data which are collected, for example, from publishing houses, governmental bodies, countries, and so on, micro-level data are collected at the level of lexical items, expressions, collocations, phrases, sentences, texts, etc. (Matthews and Ross 2010: 114; also discussed in Saldanha and O'Brien 2013: 23).

Before proceeding with introducing the research corpus, methodology and the analysis of the selected corpus, an attempt will be made in the following section to provide the reader with a brief 
overview of transitivity system according to Halliday's systemic functional grammar.

\section{Transitivity}

Transitivity is defined by Halliday as "the set of options relating to cognitive content, the linguistic representation of extralinguistic experience, whether of the phenomena of the external world or of feelings, thoughts and perceptions" (1976: 99). According to Halliday's (1994) Systemic Functional Grammar, the process of selecting certain linguistic elements and excluding others can be considered as an essential part of the process of making meanings as employing other elements from the linguistic system will lead to different meanings (Halliday, 1994, xiv). In order for the language users to reflect the mental image that they have of the world around them, they can encode and present their socio-cultural experiences in clauses (be they finite or non-finite). This is in line with Simpson (1993: 88) who is of the view that "transitivity refers generally to how meaning is represented in the clause". With this notion in mind, transitivity, which links "grammar" to "reality" (Perez 2007: 68), can be used as a tool for figuring out how language users present "their mental picture of reality" linguistically and "how they account for their experiences in the world around them" (Simpson 1993: 88).

In a transitivity-based analysis, several processes can be touched on as to whether they represent an event, action, behaviour, saying, state of mind, state of being or state of existing. These processes, which "are organized in configurations that provide the models or schemata for construing our experience of what goes on" (Halliday and Matthiessen 1985/2014: 220; emphasis in the original), can be classified into processes of happening, processes of doing, processes of behaving, processes of saying, processes of sensing, processes of being and processes of existing, respectively. To identify the type of each process, special attention is paid to the verb used in the process. "Material verbs mark the material process, verbal verbs mark the verbal process, mental verbs mark the mental process, linking verbs mark the relational process, behavioral verbs mark the behavioral process, and there and non referent it mark the existential process" (Isti'anah 2014: 163). In studying these different types of processes, three main components should be given serious consideration. They are 1) the process itself normally expressed by a verbal group, 2) the participants typically realized by a nominal group, and 3) the circumstances associated with the process typically expressed by an adverb or a prepositional phrase.

To communicate the dynamism of the image, there should be a process. As hinted above, there are several types of processes, viz. material, mental, verbal, existential, relational, and behavioural. In each process, there are certain participants (be they obligatory or optional). To further communicate the dynamism of the image that language users (be they writers or speakers) have of the world around them, they resort to utilizing different types of circumstances to provide extra information on the manner, time, place of, or the reason for the process. Although circumstances are peripheral to the clause, they contribute to the overall framing of the process (Simpson 1993: 90). Therefore, deleting or changing the circumstances employed by the language user through translation may well impose on the scene different content specifications and thereby create a different mental image.

Halliday's transitivity model (1994) is adopted in the current study as it offers effective toolkits to analyse and describe the original text. Further, it produces a repertoire of features of the original text, which is then compared to the corresponding profiles of the target text with the aim of identifying a) the similarities and differences between the source text and the target text and $b$ ) whether the translators have produced an accurate mental image or not. Have they changed the processes along with their participants and circumstances? If yes, or even no, does that affect the translation quality and create a completely or slightly different mental image? 


\section{Methodology}

\subsection{Research corpus}

The research corpus consists of an original Arabic text and its English translation. The original text الثبّاك والساحة The Window and the Courtyard was written by Mahmoud Abdulwahhab. Abdulwahhab was born in Baghdad (Iraq) in 1929 and died in Basra (Iraq) at the age of 82. Together with Mahdi Issa Al-Saqar, Abdul-Malik Nuri and Fuad Al-Takarli, he is considered a pioneer of the Iraqi short stories. In addition to writing short stories, he had been well-known for writing novels and literary criticism. He graduated in the early 1950 s from the University of Baghdad, College of Writers and worked as a teacher. Later, he was appointed as a director of Basra School. Further, he worked as a ticket seller and then as a manager of one of the cinemas in Basra.

The story used in the current study was published in 1997 and republished in 2011 in a collection of short stories under the title رائحة الثنتاء The Scent of Winter. The text was translated by Ramadan Sadkhan (Assistant Professor of Linguistics and Translation at the University of Basrah, College of Arts, English Department) and Fred Pragnell (translator and series editor of a series titled Translating Arabic Literature).

\subsection{About the story}

The short story used in the current study is set in scenes, taking its theme and details from realistic situations. The story unfolds in an unnamed Arab country and the writer does not locate the main characters in any particular place or time, thus evoking in the minds of his readers certain memories and imaginations. None of the characters presented undergo any change or development throughout the story.

The story is divided into six related parts by the writer who numbers but does not name them. The first part is descriptive, describing one of the windows of an elementary school. The window looks out upon the yard of the school. On the outside, the window frame has faded and is potmarked. On the sill, $30 \mathrm{~cm}$ wide, there are sparrow droppings. The top of the window is a semi-circle with triangular red and yellow pieces of glass, through which there pierces a ray of light which projects onto the wall opposite a quivering spot of light and a line tapered in the middle.

The second part, for its turn, begins with the description of the courtyard of the school where one of the two sides of the courtyard ends with a wall cracked from the top, and then with an unpaved alley. At the bend lies a deserted room, built of mud bricks, used for washing the dead. Inside the yard there are two stands in the basketball court, with two white lime lines designating the end of the court, and meeting the two side lines that separate the yard from an overstretching humid veranda that leads to the administration and teachers' rooms. On the opposite side, there is a desolate garden in which there stand tall thick gummy cherry trees, and which is covered in places with clumps of yellowing grass. At the end of this part, the writer invites his readers to place their perspective points somewhere in the schoolyard, looking at two students throwing a ball to each other, and from which a line of viewing moves in a prospective direction forward to focus on the ball, while rolling down towards the veranda in the corridor leading to the administration room and being followed by one of the students.

In the third part, which is presented through narrative, the writer opts for certain grammatical forms, thus inviting his readers to place their perspective points somewhere in the schoolyard, looking at another student while spinning around the courtyard of the school, and then from which a line of viewing moves in a prospective direction forward to focus on a group of students while walking in one of the classes. Then, the readers are induced to locate their perspective points somewhere outside the classrooms, looking at two female teachers as they make their way to the classrooms and from which a line of viewing moves in a prospective direction forward to focus on one of the two female teachers while entering one of the classrooms. Then, the readers are invited by the 
writer to locate their perspective points somewhere inside the depicted classroom, looking at the students as they take their seats.

In the fourth part, the writer induces his readers to place their perspective points somewhere in the schoolyard, looking at the janitor while he is standing at the door of the classroom, turning towards the end of the veranda, raising his head towards the sky, coming back, closing the classrooms, wiping his hands and face with his handkerchief and dashing out into the courtyard. Then, from the janitor a line of viewing moves in a prospective direction forward to focus on a black cat as it leaps into the middle of the courtyard, shaking off the drops of rain, jumping to take refuge under the gummy cherry tree, coming out again towards the veranda, and then curling itself up under a nearby staircase.

In the fifth part, the readers are invited by the writer to place their perspective points somewhere inside one of the houses, looking at a woman at her forties while she is looking out of the window before shutting it, moving inside the room, sitting down at a small table opening a box, taking out a pair of scissors and a needle and starting to sew a button. The woman can be seen by the reader, as an event observer, by adopting a proximal perspective. Next, the writer induces his readers to place their perspective points somewhere inside another room, looking at the woman's son as he lies on the bed, contemplating the tea pot with its flattened strainer and gazing at the tapestry in front of him. At the end of this part, the readers are invited to place their perspective points somewhere outside looking at two people jumping onto a bus, from which a line of viewing moves upwards to zoom in on the rain as it pours down on the roofs of houses, television aerials and treetops.

In the sixth part, which is descriptive, the writer invites his readers to place their perspective points somewhere outside the depicted school looking at the window that is wet from the rain, and from which a line of viewing then moves in a prospective direction forward to focus on little muddy streams that run down in an uninterrupted flow into the yard of the school. Then, the readers are induced to shift their focus of attention towards one of the streets leading to the school, looking at different people who are sheltering from the rain under the balconies of houses, and under newspapers and their own coat collars.

The next section describes my rationale for selecting this text and its translation for my analysis, using Halliday's transitivity model.

\subsection{Rationale}

I chose this sample text for four reasons:

1) This sample text, to the best of my knowledge, has not been used before by any researcher to study any socio-cultural phenomenon.

2) I have read most of the author's literary works, thus being familiar with his way of writing. In addition to this, we (the author and I) are from the same city in Iraq. Therefore, there must be a certain degree of familiarity with concepts, objects, entities and events that are used in the story.

3) I know the translators personally, and that will help a lot in terms of discussing any ambiguous issues that may need clarification.

4) Prior to selecting this sample text, I have gone through many literary works written by the same author and I found out that the author in this particular sample text, unlike in other ones from his pen, employs all transitivity processes.

\subsection{Procedure}

Building on an approach to reading visual images proposed by Gunther Kress and Theo van Leeuwen (1996) in which they state that visual images can be read as individual texts, the view is held in this study that meaningful texts create certain mental images in the mind of the reader, building on 
his/her socio-cultural experiences and encyclopedic knowledge. In studying the images conjured up in the mind of the reader, two processes are given full consideration while reading the segments of the text at hand. They are

1) conceptual processes focusing on the represented participants, such as people, places, objects, etc. They are presented conceptually.

2) presentational processes focusing on the represented actions, events, etc. They are presented narratively.

In analysing the segments of the original text and comparing them with their translations, I relied on the mental images conjured up in my mind. But before conducting this task, I extracted the following short paragraph from the sample text and identified the two types of processes:

وقف الفرّاش عند باب الصف ثم استذار نحو نهاية الطارمة ورفع رأسه إلى السماء، ولما وجدها متجهمة بالغيوم عاد بعجلة يغلق أبواب الصفوف وينصرف.

In the above example, while the represented participants are

$$
\text { وقف، استدار، ، رفع (رأسه)، وجد، عاد، يغلق، ينصرف، الطارمة، السماء، غيوم }
$$

To make sure that the above example creates similar mental images in the minds of others as well, I asked three native speakers of Arabic holding a Ph.D in either Linguistics or Translation Studies to read the above example carefully and identify the represented participants, actions and events. To avoid the connotation that may arise from the use of certain technical terms, I asked them this open-ended question: Having read and understood the text, what do you see in terms of people, places, objects, actions, etc.?

Apart from the represented participant طارمة which means a roofed platform along the outside of a building, level with the first floor (see below), the three raters confirmed that they had seen

1. these represented participants: a janitor, classrooms along with their doors, sky and clouds;

2. these represented actions and events: standing, raising (his head)/looking up, realizing, coming back, closing (the doors), and leaving.

Having realized that the three raters had actually enjoyed this task, which was not a timeconsuming one, I asked them to go through the whole sample text to give feedback on all the segments in terms of represented participants, actions and events. All three confirmed that they had seen similar represented participants, actions and events, apart from the represented event دوّ which roughly means to really get on somebody's nerves by doing certain annoying actions, and the represented participant طارمة veranda as stated above. They failed to capture the intended meanings of these two words as they are dialect-specific - they are used in Iraq, and the raters do not have the same Iraqi dialect in common with the author and researcher.

\section{Data Analysis}

The current study is not intended to be a comprehensive investigation of the transitivity processes in literary texts, although some quantitative findings will be presented. Rather, the aim of the study is to illustrate how these processes may produce (in)accurate mental images through translation.

There are a total of 248 finite and non-finite clauses of the material, mental, behavioural, verbal, relational and existential processes recorded in the original text that lend themselves easily to corresponding processes. As stated above, all these examples in the current study have been analysed by me by relying on the images conjured up in my own mind. 
Table 1: Distribution of transitivity processes in the source text and target text

\begin{tabular}{|l|c|c|c|}
\hline Process type & Percentage & maintained & changed \\
\hline Material processes & 84 processes, i.e. $33.8 \%$. & 82 & 1 \\
\hline Behavioural processes & 36 processes, i.e. $14.5 \%$. & all & zero \\
\hline Mental processes & 12 processes, i.e. $4.8 \%$. & all & zero \\
\hline Verbal processes & 17 processes, i.e. $6.8 \%$. & all & zero \\
\hline Relational processes & 54 processes, i.e. $21.7 \%$. & 48 & 6 \\
\hline Existential processes & 45 processes, i.e. $18.1 \%$. & 43 & 2 \\
\hline
\end{tabular}

As can be observed from the above table, 9 processes only have been changed through translation. They are 6 relational processes, 2 existential processes and 1 material process, as shown in the table below:

Table 2: Changing the processes through translation

\begin{tabular}{|c|c|c|}
\hline Target Text & Source text & Comment \\
\hline $\begin{array}{l}\text { on it there was a } \\
\text { small wooden box }\end{array}$ & تبي صغير عليها صندوق & $\begin{array}{l}\text { Here, a material process وضع عليها صندوق خشبي where the actor is } \\
\text { backgrounded in attention has been changed to an existential process, that } \\
\text { is, on it there was a small wooden box. }\end{array}$ \\
\hline $\begin{array}{l}\text { (she) started to sew a } \\
\text { button had come off } \\
\text { on to garment }\end{array}$ & |مقطو عاًً في ثوبت زراً & $\begin{array}{l}\text { The adjective مقطوع in the goal of the material process ثدأت تثبت زراً مقطو عا في has been changed to a relative clause where an embedded material } \\
\text { process is employed. }\end{array}$ \\
\hline $\begin{array}{l}\text { the window frame has } \\
\text { faded }\end{array}$ & خشبه باهت اللون & $\begin{array}{l}\text { As can be observed, the relational process خشبه باهت اللونhas been changed } \\
\text { into a material process the window frame has faded where the emphasis has } \\
\text { been placed on the act of fading, which is drawn out over a period of time } \\
\text { by the effect of the present perfect employed by the translators. }\end{array}$ \\
\hline $\begin{array}{l}\text { the bottom pane } \\
\text { (was) covered with } \\
\text { dust }\end{array}$ & 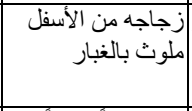 & 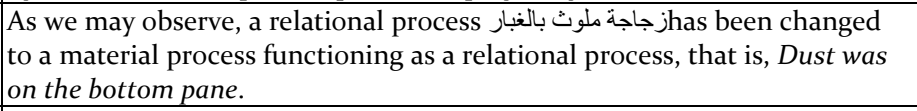 \\
\hline $\begin{array}{l}\text { she paints a } \\
\text { frightening picture }\end{array}$ & تبدو شكلاً مخيفاً & $\begin{array}{l}\text { Here, a relational process تبدو شكلا مخيفا has been changed to a material } \\
\text { process used metaphorically to describe the way in which the teacher was. }\end{array}$ \\
\hline $\begin{array}{l}\text { there were patches of } \\
\text { black clouds in the } \\
\text { sky, }\end{array}$ & | السود في السمعاء الغيوم & $\begin{array}{l}\text { Here, the process of being in كانت قطع الغيوم في السماء has been changed to an } \\
\text { existential process, that is, there were patches .... }\end{array}$ \\
\hline $\begin{array}{l}\text { scraps of paper and } \\
\text { dust swirl around in } \\
\text { the wind }\end{array}$ & 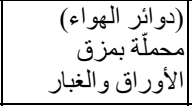 & $\begin{array}{l}\text { In this example, a process of being دو ائر الهواء محملة بمزق الأوراق و الغبار has been } \\
\text { changed to a material process, that is, scraps of papers and dust swirl } \\
\text { around in the wind, thereby materializing the depicted scene. }\end{array}$ \\
\hline $\begin{array}{l}\text { at the bend lies a } \\
\text { deserted room, built } \\
\text { of mud bricks, }\end{array}$ & غرفة طبنية مهجورة فنعفه، & $\begin{array}{l}\text { In this existential process, the existent غرفة طينية مهجورة has been changed to } \\
\text { a material process in this non-finite clause a deserted room built of mud } \\
\text { bricks, thus materializing the depicted scene. }\end{array}$ \\
\hline $\begin{array}{l}\text { inside the yard there } \\
\text { are two stands, with } \\
\text { two white lime lines }\end{array}$ & 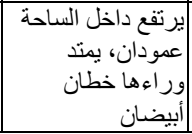 & $\begin{array}{l}\text { Here, the existential process يمند ور اءها خطان أبيضان has been changed to a } \\
\text { non-finite clause with two white lime lines that indicates a process of } \\
\text { having, i.e., they have two white lime lines. }\end{array}$ \\
\hline
\end{tabular}

Having studied the processes along with their participants and circumstances and compared them with their corresponding processes in the target text, I have noticed the following issues:

1) the processes have not been changed through translation, with the exception of the 9 processes discussed above;

2) in some parts of the text, the participants have been changed, thus affecting the translation accuracy and mental image conjured up in the readers' minds;

3) to produce accurate mental images, it is not enough to pay extra attention to the process itself along with its participants and circumstances, but adequate consideration should also 
be given to

a) the interaction between the participants of the process and the flow of energy

b) force dynamics

c) distribution of attention

d) time lapse

e) metaphorization

In what follows, these issues are given full consideration. Due to space limitations on the one hand, and since the same method of application will be followed throughout on the other, it is impractical to present and analyse the whole range of processes used in the original text. Therefore, 10 extracts representing different processes taken from the original story are considered. These examples chosen to be analysed in this section are representative for other instances.

To make the task of analysis easier and enable the reader to follow the thread of argumentation more easily, the source text along with its translation is divided into smaller parts containing a sentence, or a group of related sentences, reflecting a complete idea.

\subsection{Changing the participants}

Only two examples of changing the participants of the process were detected, as shown below:

$$
\text { بيلقف الثاني الكرة، تستكين بين بيبه. بطبطب الكرة على الأرض فتتواثب عبون الصغار تتابعه. برفع ذراعه البينى في الفضاء، بتشبث الصغار }
$$

The second catches the ball which rests in his hands. He bounces the ball on the ground and the eyes of the child jump as they follow him. He raises his right arm in the air, and the child clutches his hands.

In the second part يتلقف الثاني الكرة، نستكين بين يديه. يطبط الكرة على الأرضة (لكرة there are three material

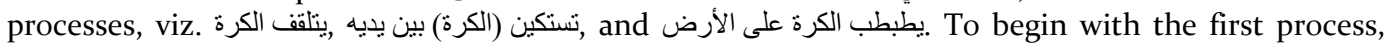
the implicit pronoun هو (the (the catch) is the process of doing, and (the ball) is the goal. In the second material process, there are two acts, namely the act of catching the ball and the act of holding it without any time gap. The act of holding functions as a possessive relational

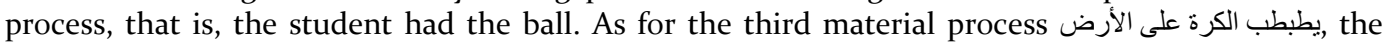
هو (the) is the actor, يطبط (to bounce) is the process of doing, الكرة (the ball) is the goal, and على الأرض (on the ground) is a redundant adverb of place - had the translators deleted it, the mental image would not have been affected.

In the third part تتو اثب عيون الصغار تتابعه, there is a material process تتواثب عيون الصغار (the eyes of the children are jumping) used metaphorically to encode the movement of the children's eyes on the one hand, and the implicit act of paying extra attention on the other. It can be looked on as an implicit behavioural process where الصغار (the children) is the behaver, ينظر (to look) is the process of behaving, and بتركيز عالٍ (attentively) is an implicit circumstance of matter. This material/behavioural process is implicitly joined with another material/behavioural process عيون الصغار تتابعه (the children's eyes were following him).

In the fourth part يرفع ذراعه اليمنى في الفضاء، يتشبث الصغار بيديه there are two material processes,

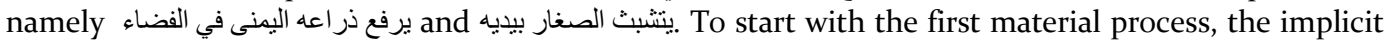

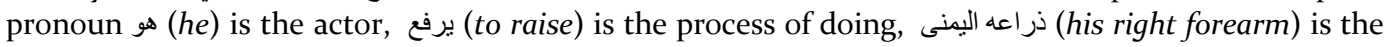
goal of the process, and في الفضاء (in the space) is a redundant location circumstance construing the extent of the unfolding of the process of raising his forearm in space. As far as the second material process is concerned, الصغار (the children) is the actor, يتشبث(to clutch) is the process of doing, and يديه(his two hands) is the goal.

Changing the lexical item الصغار (children) which is in the plural form in the original text to the child in the target text does not change the process itself, but produces a completely different mental image as one of the participants has been changed from plural to singular, thus affecting the translation accuracy. This can be modeled as follows: 


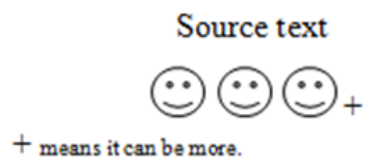

Target text

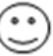

+ means it can be more.

However, changing the lexical item فضاء (space) to air or even deleting the phrase في الفضاء or in the air does not produce a different mental image as, logically speaking, when we hear or read that somebody raised his/her hand or arm, we will automatically create a mental image where the hand or arm is raised in the air. Similarly, changing the lexical item ذراع (forearm) to hand through translation does not affect the mental image conjured up in the minds of the target-language readers as the act of raising somebody's forearm implies the act of raising his/her hand.

Following is the second example:

$$
\text { أغلق الفرّاش أبواب الصفوف ومسح بيه ووجهه بيثماغه وأسرع، بحيوية خارج الساحة. }
$$

The janitor closed the classrooms, wiped his hands and face with his handkerchief and dashed out into the courtyard.

As can be noticed, in the original text the lexical item أبواب (doors) is resorted to by the writer, and thus it is foregrounded in attention. However, in the target text, it is backgrounded in attention, but it can be easily evoked as it is still in our scope of prediction. Here, an example of whole-part ways of seeing has been utilized by the translators when opting for to close the classrooms to mean to close the doors of the classrooms. Such a change through translation does not change the mental image in our mind. In a similar vein, the lexical item يد (hand) has been pluralized in the target text. Again, this does not change the mental image conjured up in our mind. This is because in order to wipe your hand with a handkerchief on your head you need to use both your hands.

\subsection{Action-chain schemas}

In an attempt to represent a certain socio-cultural experience, language users utilize certain processes and decide in advance the participants and circumstances. Added to this, they also determine in advance the action-chain schemas to represent the flow of energy between the participants in a given process whether it is bidirectional, that is, a reciprocal action schema, or unidirectional, that is, an asymmetrical action schema. To create a similar mental image, these action-chain schemas need to be given adequate consideration by the translators while dealing with the text at hand. By way of explanation, let us consider these examples:

In the yard two schoolchildren are throwing a ball to each other....

في الساحة طالبان بتبادلان الكرة ...

Here, the writer decides to encode and present his ideas by employing an implicit existential process: an existent طالبان (two students), an implicit process of existing يوجد (there are/were), and an adverb of place في الساحة (in the courtyard). This implicit existential process is conjoined implicitly with the material process يتبادلان الكرة (they are exchanging the ball): the implicit pronoun Lه (they) referring back to the two students is the explicit actor and implicit recipient, يتبادل (to exchange) is the process of doing, and الكرة (the ball) is the goal, and في الساحة (in the courtyard) is an adverb of place.

As can be seen, the interaction between the two students in the scene is construed as bidirectional based on a reciprocal action schema where one of the participants cannot be ascribed the status of agent/actor and the other patient/receiver, but rather both of them are involved actively at the same time. By contrast, the verb to throw utilized by the translators can be construed as unidirectional based on an asymmetrical action schema where the transfer of energy flows from an actor/thrower to a receiver. Being fully aware of such an action-chain schema, the translators have 
added the phrase to each other, thereby evoking a similar mental image in the minds of the targetlanguage readers.

$$
\text { بيرمي الكرة بقوة إلى زميله الآخر في حين بلوح لعينيه، فجأة، شباك الدار. }
$$

He throws the ball hard to his friend when he suddenly notices the window of the house.

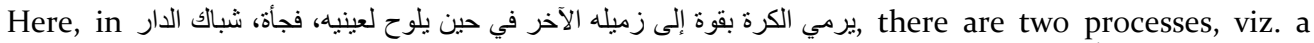

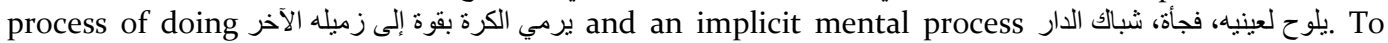
start with the material process, the implicit pronoun هو (the) is the actor, يرمي (to throw) is the process of doing, الكرة (the ball) is the goal of the process, بقوة (strongly) is an adverb of manner, and زميله (mate) is the recipient of the process. The interaction between the two students in the scene is construed as unidirectional based on an asymmetrical action schema in which the transfer of energy flows from the actor (one of the students) to the receiver (the other student).

As regards the implicit mental process, the implicit pronoun هو (to is the senser, يلاحظ notice) is the process of sensing, فجأة (suddenly) is an adverb of manner, and شباك الدار (the window of the house) is the phenomenon of the process. Here, the translators have opted for an ideational translation where the idea has been given a front seat. Had they given serious consideration to the target-language readers' expectations, they could have suggested something like the moment he throws the ball hard to his mate, the window of the house catches his eye.

\subsection{Force dynamics}

At times, the process utilized by the language user exhibits a certain force-dynamic pattern where one participant exercises a certain type of force over another or others, thus having different types of forces acting in different ways upon the participants. In this regard, Talmy (2000: 409) talks of these types of force dynamics:

a) the exertion of force

b) the resistance to such a force

c) the overcoming of such a resistance

d) the blockage of the expression of force

e) the removal of such blockage.

To make this point clear, the following examples can be considered:

$$
\text { أشارت البى طالب في الصف الأمامي. قام خائفاً. لم يجبْ. أشارت إلبه. جلس. قامت طالبة صنيرة تنبين شعرها بشربط أحمر كالوردة. جلست. }
$$

She pointed to a child in the front row. He stood up terrified. He did not answer. She pointed to him. He sat down. A little girl stood up, her hair adorned by a ribbon, the colour of a red rose. She sat down. The children's faces fell.

In this example, a number of explicit and implicit processes are employed by the writer. The interaction between the teacher and students in this scene is construed as unidirectional based on an asymmetrical action schema where the transfer of energy flows from the teacher to the students. The explicit act of pointing to one of the male students in the front row and implicit act of pointing to a female student in such a context have a force-dynamic value of forcing the goal that tends to sit to stand up and that tends to stand up to sit down, thus indicating the actor's being-able-to-do (authority). Similarly, the act of standing up and the act of sitting down indicate the behaver's willing-to-do (submission) and not-willing-not-to-do (powerlessness). Had the translators, for instance, opted for the lexical item أشار (to request) in place oint to), they would not have had force-dynamic patterns, thus affecting, to a certain degree, the translation accuracy, as the act of requesting does not indicate the addressee's submission and powerlessness, but rather indicates that $\mathrm{s} /$ he still has the right not to do whatever it is. 
على طول الجدار، من الداخل بمتل سربير مزدوج من خشب الصاج ترفرف في نهايته، على مقربة من أرض الغرفة، حاشية شرشف نظيف

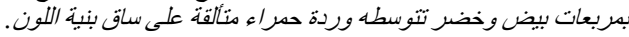

Along the wall, on the inside, there is a double bed made of teak, at the foot of which, close to the floor, there flutters the hem of a clean bed sheet with white and green squares. In the middle there is a red rose glistening on a brown stem.

In this example, an intransitive verb برفرف (to flutter) is employed by the writer to create a certain mental image in his readers' minds. The act of fluttering is characterized by an iterated multiplexity, to use Talmy's (200o) terms, as it refers to a series of delicate movements up and down and/or from side to side, and the verb to move refers to just one of these components, thus lending itself easily to being rendered as to flutter. Further, in this scene, one force-exerting entity, that is, wind, which is backgrounded in attention, makes the hem of the bed sheet flutter. To put this differently, the interaction between the wind/causer and bed sheet/causee is not force-dynamically neutral, but rather has a force-dynamic value of forcing the bed sheet that tends to keep still in normal cases to flutter.

\subsection{Foregrounding/backgrounding in attention}

Attention is one of the construal operations that need to be given adequate consideration when the image conjured up in the mind of the translator as a special reader is studied (cf. Talmy 20oo; Croft and Cruse 2004). In what follows, the three portions of the event, viz. initial, medial and final, will be paid extra attention in an attempt to identify whether the portion is foregrounded or backgrounded in attention.

$$
\text { قامت من مقعدها بهدوء، وأغلقت ضلفة الشباك البينى، وسارت على طرفي قلمها بحنر، ووجهها صوبه ثم أغلقت باب الغرفة وراءها. }
$$

She got up quietly from her seat, and closed the right side of the window, and tiptoed carefully, her face towards him and then closed the door behind her.

In the first part of this example قامت من مقعدها بهدو ؛، وأغلقت ضلفة الثباك اليمنى (She got up quietly from her seat, and closed the right side of the window), the act of walking from her seat to the window is backgrounded in attention but can be easily evoked as it is in our scope of prediction. To put it differently, open-path windowing with gapping over the medial portion of the event, that is, she walked from her seat to the window, is employed by the writer and reflected by the translators, as modeled below:

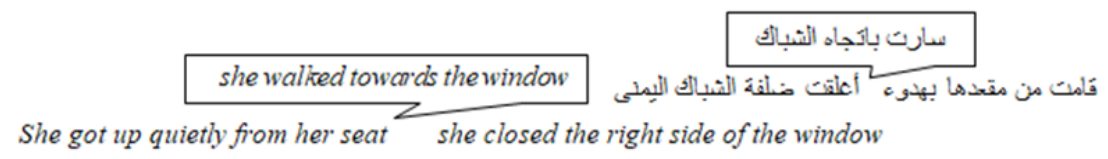

Similarly, the act of going out indicated by the phrase وراءها (behind her) is implicitly mentioned in the source text. Giving full consideration to foregrounding as opposed to backgrounding in attention, the translators have opted for an implicit act of going out, thus producing an accurate mental image.

\subsection{Time lapse}

In photography, time lapse refers to the photographic technique of taking a sequence of frames at set intervals to record changes that take place slowly over time. However, time lapse here refers to any time gap that may be created among the different acts utilized by the language user. To produce an accurate mental image, translators need to pay extra attention to these time gaps. 


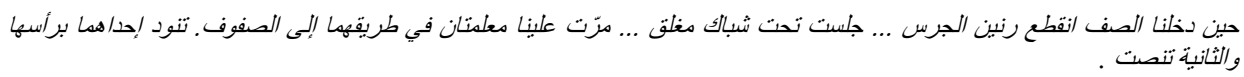

As we entered the classroom, the bell stopped ringing... I sat down under a closed window ... Two teachers passed us on their way to the classrooms; one of them shakes her head, the other listens.

In this example, the writer utilizes a number of explicit and implicit processes. Following are the explicit ones:

Action material process Event material process Behavioural process Action material process Behavioural process Behavioural process we entered the classroom the bell stopped ringing I sat down under a closed window two teachers passed us one of them nods her head the other listens

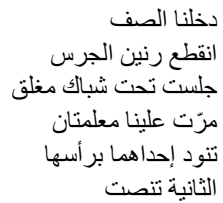

With respect to the implicit ones, one can suggest the following acts indicated by boxes:

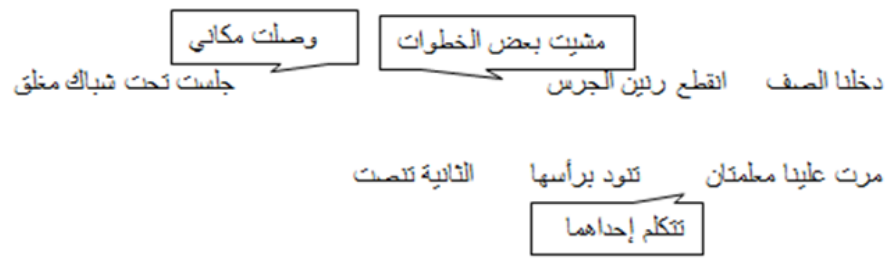

In the second process انقطع رنين الجرس, a material process in the form of an event process is used. This material process is joined to the previous one by the connector حين (while), thus indicating there is no time lapse between the act of entering and the act of the bell stopping ringing. The act of passing occurred shortly after the act of sitting, thereby indicating a time gap which has been lost through translation.

The emphasis in the acts of nodding and listening in the original text is placed on the continuity of these two acts in a specific period in the past as there is an implicit كان. However, the translators have opted for a simple present tense, which is normally used to emphasize the frequency of the acts as a matter of routine, unchanging situations, general truths, and the like. Further, the behavioural process الثانية تتصت (the other) is the behaver, and تنصنية (to listen) is the process of behaving, implies that while the first teacher was walking and nodding her head (explicitly mentioned), she was speaking (implicitly mentioned), thus indicating an implicit process of saying on the one hand, and, on the other hand, there was no time lapse between the act of nodding and the act of speaking. Had the translators paid extra attention to the sequences of the events, they would have produced an accurate mental image.

\subsection{Metaphorization}

At times, the process is utilized metaphorically by the original writer, thereby creating a relationship between the literal meaning of the process used metaphorically and the socio-cultural experience being described by the metaphor. By way of explanation, let us consider the following example where a forest is compared with an animate creature that can breathe and watch.

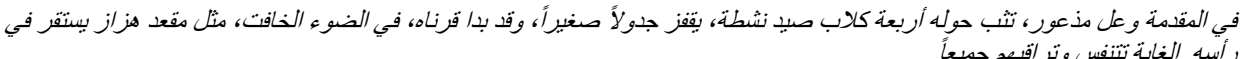

In the foreground there is a frightened ibex with four lively hunting dogs jumping around it. Leaping over a little stream, its horns appeared, in the faint light, like an upturned rocking chair. The forest breathes and watches all of them. 
In the last part of this example الغابة تتنفس وتر اقبهم جميعاً, two behavioural processes are employed by the writer in the form of metaphor where الغابة (the forest) is the behaver in both processes, تنفس (to breathe) is the first behavioural process while تراقب (to watch) is the second behavioural process. These two behavioural processes are joined by the additive connector $و$ (and), thus indicating that there is no time lapse between the act of breathing and the act of watching. Giving adequate consideration to the types of processes along with the metaphor employed by the writer, the translators have opted for an original text-oriented translation where form/image and content/idea have been taken into consideration.

\section{Conclusion}

The data of the study were qualitatively analysed by adopting Halliday's (1994) transitivity model.This was done through first identifying the types of processes along with their participants and circumstances utilized by the writer to encode and represent the world around him, and then comparing them with the processes resorted to by the translators.

It has been shown from the discussion of the data that Halliday's (1994) transitivity model can cover most, if not all, socio-cultural experiences that a language user may think of. Further, it can be applied to Arabic. It has been also shown that the processes along with their participants and circumstances have not been changed dramatically by the translators. One may conclude here that this is because these processes along with their participants and circumstances lend themselves easily to equivalent processes from one linguistic system into another; hence the reliability and practicality of this model, particularly for pedagogical purposes.

When the socio-cultural experience is expressed metaphorically, more than one process can be identified: an explicit process used metaphorically versus an implicit one. In such cases, the translators may adhere to the explicit process along with its participants and circumstances, providing that the target language allows them to do so. Alternatively, they may well try their hands at figuring out the implicit process meant by the writer, thereby having more than one local strategy. Such a decision depends on 1) the translator's global strategy adopted earlier before embarking on the actual act of translating the text, 2) the translator's competences (be they linguistic, translational, research, contrastive, etc.) that s/he has developed over time, and 3) the socio-cultural experience per se and how it is conceptualized in the source language and how it would be conceptualized in the target language.

To frame the process per se, thus communicating the dynamism of the image that they have of the world around them, language users (be they writers or speakers) tend to utilize different types of circumstances to provide extra information on the manner, time, place of, or reason for the process. By contrast, they sometimes tend to produce their message with some missing parts for various reasons. Although these circumstances are peripheral to the clause in which a certain socio-cultural experience is encoded, the translator needs to give these extra details adequate consideration as deleting or changing them may well impose on the scene different content specifications and produce a different mental image. However, some details are redundant and language-specific, thus encouraging the translators to remove them through the act of translating from language A to language B without changing the image and text-type focus.

As people in general and translators in particular have different backgrounds, commitments, attitudes, emotions, experiences, knowledge, etc., the image that they try to create while representing their socio-cultural experiences or the image that is conjured up in their minds while hearing/reading these experiences is dynamic. This fits neatly with Quine's (1960) Indeterminacy theory, in which he denies the notion that there can be an absolute standard of right and wrong in translating one language into another. Rather, he adopts a pragmatic stance toward translation, that is, a translation can be consistent with the behavioural evidence (cf. Quine 1976, 1992; Bostrom 1995). The key point is that more than one translation meets these criteria, and hence that no unique meaning can be assigned to words and sentences (Quine 1976, 1992). 
Pedagogically speaking, adopting this model in class will inevitably feed into the competences that each and every translator should have. Further, it provides the translators, particularly when they are asked to annotate their own translations and comment on others' translations, with a rich soil in which they may academically discuss the translation in question, thus developing the ability to defend their own decisions and evaluate others'. Similarly, it can be used by translation reviewers, evaluators, critics and researchers to analyse the translation and make sense of the translator's decisions at the level of an individual text.

To conclude, the socio-cultural experiences discussed in this paper are by no means comprehensive. Other experiences can be analysed, and thus other research questions may arise which will provide a focus for further research.

\section{References}

Bostrom, N. (1995). Understanding Quine's Thesis of Indeterminacy. Retrieved on April 23, 2016: www.nickbostrom.com/old/quine.html

Chesterman, A. (2005). Consilience in Translation Studies, Revista Canaria de Estudios Ingleses, 51, 19-32.

Croft, W. and Cruse, A. D. (2004). Cognitive Linguistics. Cambridge: Cambridge University Press.

Halliday, M.A.K. (1976). Notes on Transitivity and Theme in English. Part 2. Journal of Linguistics, 3 (1), 199-244. (1994). An Introduction to Functional Grammar ( $2^{\text {nd }}$ edition). London et al.: Arnold.

Halliday, M.A.K. and Matthiessen, C. M.I.M. (1985/2014). Halliday's Introduction to Functional Grammar (4 ${ }^{\text {th }}$ edition). London/New York: Routledge.

(1999). Construing Experience through Meaning: A Language-based Approach to Cognition. London/New York: Cassell.

Isti'anah, A. (2014). Transitivity Analysis in Four Selected Opinions about Jakarta Governor Election. Phenomena, $14(2), 163-175$.

Kress, G. and van Leeuwen, T. (1996). Reading Images: The Grammar of Visual Design. London: Routledge.

O'Leary, Z. (2010). The Essential Guide to Doing Your Research Project, California/London: Sage.

Quine, W. V. (1960). Word and Object. Cambridge: MIT Press. (1976). Ways of Paradox and Other Essays (Revised in enlarged edition). Harvard University Press. (1992). Pursuit of Truth ( $2^{\text {nd }}$ edition). Harvard University Press.

Matthews, B. and Ross, L. (2010). Research Methods: A Practical Guide for the Social Sciences. Edinburgh: Pearson Education Ltd.

Matthiessen, C. M.I.M. (1995). Lexicogrammatical Cartography: English Systems. Tokyo: International Language Sciences.

. (1976). Ways of Paradox and Other Essays (Revised in enlarger edition). Harvard University Press. (1992). Pursuit of Truth (2nd edition). Harvard University Press.

. (2004). An Introduction to Functional Grammar ( $3^{\text {rd }}$ edition). London et al.: Arnold.

Perez. M. C. (2007). Transitivity in Translating, the Interdependence of Texture and Context. Oxford: Peter Lang.

Saldanha, G. and O'Brien, S. (2013). Research Methodologies in Translation Studies. London/New York: Routledge.

Simpson, P. (1987). The Narrative Structure of Hemingway's The Old Man and the Sea. Belfast Working Papers in Language and Linguistics, 9, 167-227. (1993). Language, Ideology and Point of View. London/New York: Routledge.

Talmy, L. (2000). Towards a Cognitive Semantics: Concept Structuring System (Vol. 1). Cambridge: MIT Press. 